\title{
New Urbanism Theory as an Approach to regenerate the Egyptian Urban Heritage
}

\author{
Mariam, A , Abdullah ${ }^{1}$, Zeinab, Y, Shafik ${ }^{2}$ and Dalila,Y, El Kerdany ${ }^{2}$
}

\begin{abstract}
:
Recently the urban heritage of the $20^{\text {th }}$ century neighborhoods in Egypt has been facing new challenges and obstacles, such as losing a great deal of their urban harmony and architectural heritage wealth. In the contrary, the developed countries are following new urban approaches; such as the new urbanism theory; established in the late $20^{\text {th }}$ century which could protect urban heritage from the harmful effect of modernization by enhancing walkability and a pedestrian friendly environment. Walkability can control urban sprawl that has robust effects on the urban harmony of old centers. Thus, this paper seeks to explore the merits of the new urbanism approaches, aiming to draw conclusions and propose recommendations of introducing pedestrian friendly and walkability approaches in the urban regeneration projects in Egypt. The paper proposes a strategy for enhancing the efficiency of the regeneration projects in the $20^{\text {th }}$ century neighborhoods, in order to impact the Egyptian heritage conservation legislations. Accordingly, the study presents an analysis to the problems facing urban heritage in Egypt, proposing a new methodology based on inflicting adaptations and changes in the urban heritage legislations based on the new theory of urbanism. The study aims also to revive the urban harmony of historic districts, to raise awareness of heritage and to endorse the sense of belonging.
\end{abstract}

Keywords: Urban Heritage $-20^{\text {th }}$ century neighborhoods - Urban Regeneration New Urbanism Theory- Walkability

\footnotetext{
${ }^{1}$ Faculty of Engineering, Architecture Department, The American University in Cairo

${ }^{2}$ Faculty of Engineering, Architecture Department, Cairo University
} 


\section{Introduction}

The attention of the Egyptian governmental bodies in charge of urban heritage preservation during the last decades was focusing on the problems of new settlements, with the desire for modernization over regeneration. As a result, the magnificent heritage legacy and sense of the old harmonic city was irreparably damaged and helped to erase the unique features of the urban fabric and the deterioration of historic districts that reflect the architecture, socio-economic and cultural conditions of earlier eras in the history of Egypt. In addition to the dramatic changes to its social demography, since the military revolution in 1952 helped in the erosion of the original social texture of the historical areas, and caused a continual social mobility that replaced the original inhabitants by those who are social, economic and cognitive values are incompatible with the cultural context of those valuable areas. Accordingly, the rate of the demolition and violations actions that have been taking places for the past decades to significant villas, urban spaces, and many historic buildings, was very high.

However, recently Egypt witnessed many urban regeneration projects mostly in downtown Cairo. These projects that have been adopted by the government suffered from many obstructions and had many shortcomings. They lacked the efficient regeneration process and did not address or tackle the socio-economic and environmental aspects. Thus, they were not prosperous enough compared to those projects conducted in the developed countries that followed the new theories. Not to mention that the Egyptian interventions lacked a complete vision, strategy and plan, and contributed only to the beatification of the historical texture whether on the architectural scale or urban scale.

However, in the developed countries, in the 1960s an interest arose in conserving the inner cities with a focus on rehabilitating social life in the public space. And new cities tried to adapt the looks and feel of historical towns, even with more space for pedestrians in the city center and controlling urban sprawl [1]. Noting that in the last years of 1980s, a huge volume of theories of new urbanism movements arose based on humanistic urbanism. These modern theories aimed at developing communities that would provoke the pedestrian friendly environment which would successfully enhance the social bond between residents and raise the awareness of the value of the built heritage, while enhancing the urban quality of life and preserving their urban heritage. Those new urban planning approaches and theories advocate a return to urban design principles of pre-automotive and modernization times, where social and economic life took place on the squares and streets, and break new ground by blending contemporary and traditional design principles.

\section{Problems facing urban heritage in Egypt:}

It is hypothesized that the main reasons behind the problems facing our valuable urban heritage recently are related to the social aspect, whether by the crucial 
changes in the socio economic aspect decades ago or the absence of the social bonds between residents and disappearance of social life that took place in the streets and squares, which plays a very important role in the awareness of layman of the heritage value. However, this flaw in the social aspect goes back to the thirties of the twentieth century, where it witnessed the increase in using motor private with the transportation vehicles and the bus as a new public transportation. Consequently, the streets lost its intimate scale and transparency, and became a mere service road, devoid of social public life. Moreover, the transformation of city economy with every political regime, especially after the Revolution of 1952, with its consequent socioeconomic changes, such as nationalization in sixties, open door policy in seventies leading to privatization and modernization in the 80s and 90s; resulting in the social mobility and an unpredictable enlargement of the city master plan, leaving the historic neighborhoods in a massive decay behind. Not to mention that our heritage laws, systems and legislation did not fully protect the built heritage neighborhoods, this encouraged urban sprawl over urban preservation [2].

\subsection{Car invasion :}

Cars and car traffic have been a pressing urban planning problem for more than 60 years. At the same time the sense of city proportion and scale has been gradually become more and more cars oriented. As the growth and extension of Cairo and decentralization was more encouraged after the use of cars and tramways which encouraged opening vast peripheral areas to urban settlement.

This car invasion and violation stared in the 30's of the twentieth century; as the period from 1900 to 1930 saw the introduction of nearly 1,200 new automobile designs with various means of self-propulsion [3].The reflection on Egypt was gradually enormous, as one of the first cars brought into Egypt was belonging to Khedive Ismail's grandson, Prince Aziz Hassan in 1904, the prince made the 210 kilometer journey from Cairo to Alexandria in over ten hours despite the hundreds of difficulties due to the absence of roads and bridges. After this tour, Egypt was progressively invaded by these vehicles. By the end of 1905, there were around 110 motorized vehicles in Cairo and 56 in Alexandria.

With everyone becoming car crazy, drastic changes befell Egyptian cities' streets, sometimes involving the razing of trees as roads were widened and asphalted to accommodate the new cars, then new roads were laid out linking most of the country's cities and towns [4]. By 1930 more than 3000 of all category vehicles licensed in Egypt, cars were becoming the norm not the exception .Bridge builders from all over the world were invited to submit their tenders [5]. Moreover, the introduction of the car in Cairo widened the gap between the old and the new communities. The old streets were not suitable enough for vehicles, whether in the width, pattern or condition. Thus, the old part depended on donkey or foot while the new ones depended on new technology for transportation. In the meanwhile the extension and growth of Cairo city and decentralization was more encouraged after the use of cars and tramways where the latter opened vast peripheral areas to urban settlement [6]. 
Not to mention that, later in the 70 s during Sadat regime the way to the dominance of the private car began. Sadat's aim was to provide every Egyptian with a private car. During this time, more than half of the existing 120 kilometers of tram tracks were replaced by road surfaces for cars. Accordingly, there were car prioritization and the loss of a more dominant mode of transportation. According to this attitude, the fuel was subsidized by the state in that time. This encouraged inefficient car use, for short trips or with only one person in the vehicle [7].

Consequently, there were relative car problems that affected the architectural and urban wealth such as parking problems; which worsens air quality, raises the cost of housing, decreases public revenue, undermines public transportation, increases traffic congestion, damages the quality of the public realm, escalates suburban sprawl, threatens historic buildings, weakens social capital, and worsens public health [8].

Bearing in mind that, the long term contact to vibrations can cause damages in buildings, such as cracks, which in critical cases could result in collapse, especially in historic buildings, as ground endured vibrations are generated due to road traffic, railway, blasting, construction induced, machine, pile driving etc. Accordingly, the busy streets of Cairo create inhospitable conditions for socializing, due to the high levels of car ownership, with the insufficient capacity of public transport system leading to destroying our old communities and neighborhoods [4].

\subsection{Social mobility :}

Galal Amin (2009) argues; the primary dominant force producing the Egyptian new lifestyle was the social mobility driven by the political orientations [9]. According to some political decisions and laws ; the accessibility of old $20^{\text {th }}$ century neighborhoods to the average Egyptian was increased, which transformed it from a high-end quarter to a destination of the middle-income and low-income groups who do not have neither sense of belonging to the historic area nor to its value. There many reasons behind the social mobility throughout the history due to governmental actions and polices which will be discussed next.

\subsubsection{Nationalization after 1952 Military revolution:}

Cairo remained attractive until the mid of $20^{\text {th }}$ century with the break of the 1952 revolution. This political shift with its economic adjustments had a significant effect on social changes, texture and culture lifestyle. The user groups, the land uses, and the urban fabrics have changed, as the departure of the foreign community had a robust effect on Cairo's twentieth century neighborhoods [9]. The government quickly gained control over many of the town's villas, empty lots and private projects, resulted in an allocation of the elite, and an advancement of the middle and lower middle classes, causing unsteadiness in the demographic map of Cairo [10]. Most of these assets were eventually transferred to one or another public schools and sector bank, the most prominent being bank Nasser. Banks and government agencies became real estate managers, developers and agents [11]. 
Moreover, in the sixties, by the nationalization policy (1961), a centralization process has resulted in an unpredictable enlargement of the city master plan, accompanied by socioeconomic changes of the inhabitants, shifting culture and urbanism towards socialism. Foreigners were negatively impacted by Nasser's nationalistic economic policies and the increasing tension with the west following the 1967 war prompting the majority of them to leave the country, which caused a huge change in the social configuration. Thus, the original inhabitants were replaced by governmental workers and army officials and other middle-income families. Not to mention the migration of the canal cities habitants during the war after the1967 Arab-Israeli war was enormous. Unfortunately, these new immigrants tended to have less respect for the historic buildings without any awareness of the importance of the built heritage that they had inherited, which also affected the harmony of the urban heritage the most [2].

Consequently, the Nasser regime's socialist ideology inspired several legislations aimed to lower and control rents and increase the power of tenants. These legislations evolved over 20 years (1952-1974) and extended to Sadat's presidency creating a great discouragement for property owners to invest and maintain their properties, impacting the real estate market in the country as a whole, this rough rent control laws, resulted in negligence and lack of maintenance to old buildings and accordingly destroying the urban harmony[7].

\subsubsection{Open door policy:}

In the seventies, Cairo's culture and urbanism were strongly affected with the opendoor policies, which have started after the 1973 victory that has shifted the administrative orientation towards capitalism. The national urban policy was directed towards developing desert lands and creating new cities instead of revitalizing the existing urban fabric. The consequent commodification of land in new areas resulted in developments that are socially exclusive of the majority of the population, leaving central and old locations neglected due to its acquired low socioeconomic status. The neoliberal city which is more shaped by the logic of the market than by the needs of its inhabitants, increased class segregation in a city such as Cairo, which impacted city planning policies [12]. Bearing in mind that, Sadat's embracement of a neoliberal political economy ideology impacted city planning policies.

\subsubsection{Internal and external migration:}

A tremendous shift in the formulation of the middle class and in the urban configuration coincided with the exploration of oil in the gulf countries that has resulted in a new reconstruction of the social classes, constituting a new social class, which has contributed to a new urban irrelevancy in the new districts and suburbs with their comeback from oil countries for home upgrading. Accordingly, the gap between socio economic groups has been widened and the demographic structure has mingled. Not to mention, the rural immigrants, with the unqualified class that extensively worked in the capital, living on the margins and the 
peripherals of the city, composing the early urban slums and squatter settlements. Consequently a quick deterioration has spanned along the original older districts of the city because of over population, and lack of maintenance and renewal projects [10].

\subsubsection{Privatization and Modernization:}

In the nineties of the $20^{\text {th }}$ century, what also affected the social mobility were the dramatic changes in the desert land around Cairo, in its physical, cultural and social features, with the foundation of the ring road and several road conjunctions which attracted many investors who started new housing projects, establishing new communities for upper middle class families [13]. Moreover, after the political regime shifted its economy towards the privatization in $90 \mathrm{~s}$, the investment sector has swept like a flood, building also its own residential compounds outside the borders of the city, with some educational, cultural, medical and commercial facilities. Creating opportunities for the building sector to flourish and the demand of the out-side-the city new residential compounds to increase, creating a new inflation in the land prices, building costs and craftsmanship wages [14]. Accordingly, a considerable portion of the socially higher population living in nearby overcrowded Cairo districts chose to move seeking a better quality of life in those new communities.

Noting that the rapid growth of Egypt's population and the insufficient urban governance in the last few decades which goes for expansion of newly built urban settlements rather than upgrading the fundamental existing ones, and focusing on the problems of new settlements through the formal and informal processes, with the desire for modernization, led them to believe in new and modern style instead of revitalization [15].

\subsubsection{Globalization:}

As a result of the new strategies, arose the globalization, which has affected people's relation through the way they communicate in between in addition to their linkage to places. It increased the integration of economies, societies, and cultures around the world, which made significant changes in the social classes and lifestyle, leading to homogenization of culture, where the life style of people is diffused. Thus, people, especially who belong to traditional cultures and old districts, are torn between the culture they are newly exposed to and their own. As traditional societies are struggling to grasp to getting in the face of the new waves while at the same time taking benefits of the new technology to solve their problems, trying to adjust themselves in order to survive in the new circumstances. Accordingly, the urban form of cities has witnessed a large shift as a result of the globalization. This was evident in its physical appearance through what is called standardization of new urban systems in the new settlements; in the width of roads, heights of buildings, zoning and segregation of use...etc.[16]. 


\subsection{The flaws in the administrative system management of urban heritage preservation :}

Egypt witnessed two parallel movements during its modern history; the first is conservation that focused on documenting individual buildings ignoring their surrounding urban fabric, the second is the overwhelming desire of development, which focused on the modernization of cities regardless of individual monuments or historic urban fabric. After the revolution of 1952, which had aspirations of development and modernity; the new regime paid little attention to conservation. The majority of available state resources were directed to build factories and economic residential projects for low and middle emerging classes. This trend continued to increase till the sixties; planners overlooked the significance of historic fabrics, and dedicated their efforts to innovating smart plans for land use and traffic problems. Their plans caused the demolition of some heritage resources. Never the less, during the last three decades of the twentieth century, the majority of monuments in Egyptian cities became surrounded by informal settlements and unplanned areas as a result of the population explosion and rapid urbanization. Focusing on modernization plans carried out by consecutive regimes, in addition to market forces and social transformations radically changed the original fabric of Egyptian cities while ignoring their heritage resources.

As a result, the division between conservation practices and those of development still remains. Moreover, the desire of development has been overwhelming compared with conservation practices, which have been only focusing on documenting individual old historical buildings ignoring their surrounding urban fabric. Consequently, a great number of old buildings were destroyed. Thus, nowadays, the Egyptian administrative system that manages and governors those contexts on different governmental levels is ineligible to deal with their complexity, as it is characterized by immoderate centralization, multiple authorities, bureaucracy as well as the incapacity of involving the community in the process of decision making. Furthermore, multiple authorities lead to an enfeeblement of responsibility, an extremely inefficient system and dissipation of national financial resources.

Therefore, the enormous problems torturing the Egyptian urban realm are caused by failures of different administration systems that govern the urban process. Instead of enhancing decentralization, and empowering the community by amending the laws managing the urban realm, national and local authorities make either weak and nonintegrated attempts or hyper controlled interventions for historic areas [17].

Moreover, the management system is characterized by a centralized domination with a very limited role played by local authorities and the apparent absence of effective public participation except in individual revitalizing cases. It is also characterized by the phenomenon of multiple actors and agencies that work in one area without coordination, which always leads to an overlap, conflict in the responsibilities and duties and the loss of massive efforts, time and money [14]. 
Official conservation efforts have been characterized by insufficient successive governmental developmental efforts towards finding practical solutions for urban heritage areas. These efforts have usually failed as they have implemented general and rigid developmental policies that are not compatible with the nature of these areas and their cultural value [18].

However, the Egyptian policies unfortunately, have not been successful in the preservation process during the last decades .They lack a long-term vision and tend to push more for narrow problem solving methodologies. The policies failed to properly organize the roles of all involved actors and mostly have avoided the role of the local communities which is considered a robust key role in heritage preservation strategies [19].

However, it is worth mentioning that On April 2016, the head of NOUH (Mohamed Abu Seda) stated that NOUH is in need for developing laws for protecting historic buildings, including law 144 for $2006^{3}$ concerning listing buildings with special value. Therefore, a committee from NOUH and the ministry of housing and other specialists worked on providing a modified law, in order to present the developed law to the Egyptian parliament to have the judicial right, and stop the vandalism and encroachment on buildings of heritage value.

The committee attempted to improve the relation between the government in charge of saving heritage and property owner's rights, not to mention providing appropriate funding for maintenance of old buildings, and also achieving a middle ground for the management system with the owners by offering several alternatives for shared management [20]. Yet, all the efforts are targeting saving architectural buildings. They did not mention any modifications for law 119, $2008{ }^{4}$ regarding saving urban heritage, as the only legislations that are being offered by the government are presented by NOUH in their guidelines booklets. Never the less these guidelines, did not mention any vision, plan or strategy for the urban heritage protection, they keep on providing separate ideas without even sometimes offering solutions, or how the urban heritage should enhance the socio economic aspect otherwise the regeneration would fail as soon as the project ends.

\section{Case studies of urban heritage regeneration in downtown Cairo:}

Recently Cairo's downtown witnessed several urban heritage conservation and regeneration projects. The period (2004-2011) witnessed the first initiative that was adopted by Cairo Governor Abdelazim Al-Wazir. He was the first governor in decades to take particular interest in rescuing the deteriorated downtown. He established and headed the Board of Trustees of Historic Cairo (BTHC) in January 2008 .It was established to be the custodian of downtown Khedival Cairo, promotes

3 Law 144, 2006: regulating the demolition of non-dilapidated buildings and establishments, and the Preservation of Architectural Heritage, providing protection measures for monuments and listed buildings.

${ }^{4}$ Law 119, 2008: assumes the responsibility of NOUH, and other administrations in the establishment and implementation of legal documents, for urban harmonization and proposing relevant legislation; also for outlining guidelines for future development in coordination with other related parties. According to this law, NOUH is responsible for identifying heritage areas and buildings and setting controls and principles for their preservation, and also for proposing necessary actions related to property rights 
and oversees the rehabilitation of the architecturally-significant buildings and to revive the area as a whole and to escape the bureaucratic administrative hustle caused by the division of downtown Cairo under two administrative districts Hay Gharb (west) and Abdin.

The board included three branches: the executive (the governorate overseeing renovations undertaken), the technical advisors (NOUH experts offering technical advice on restorations), and the financial support (the heads of the central bank and other national and investment banks and the Misr Insurance Holding Company (MIHC) to secure funding). The board of trustees also included Misr Real Estate Assets (MREA), which is the largest real estate owner in the area [21].

However, they had a three- zone plan to revitalize the area, which has been reported in 2010 that EGP 5.6 million were allocated to renovate 241 historic buildings in downtown as part of the plan. The three intervention areas were: buildings directing the $6^{\text {th }}$ of October bridge looking over Ramsis street up to 'Abd alMin 'im Riad Square, buildings and also repaving in Țalat Harb Square, then Qasr Al-Nile street from Opera up to Tahrir Squares as shown in figure 1.

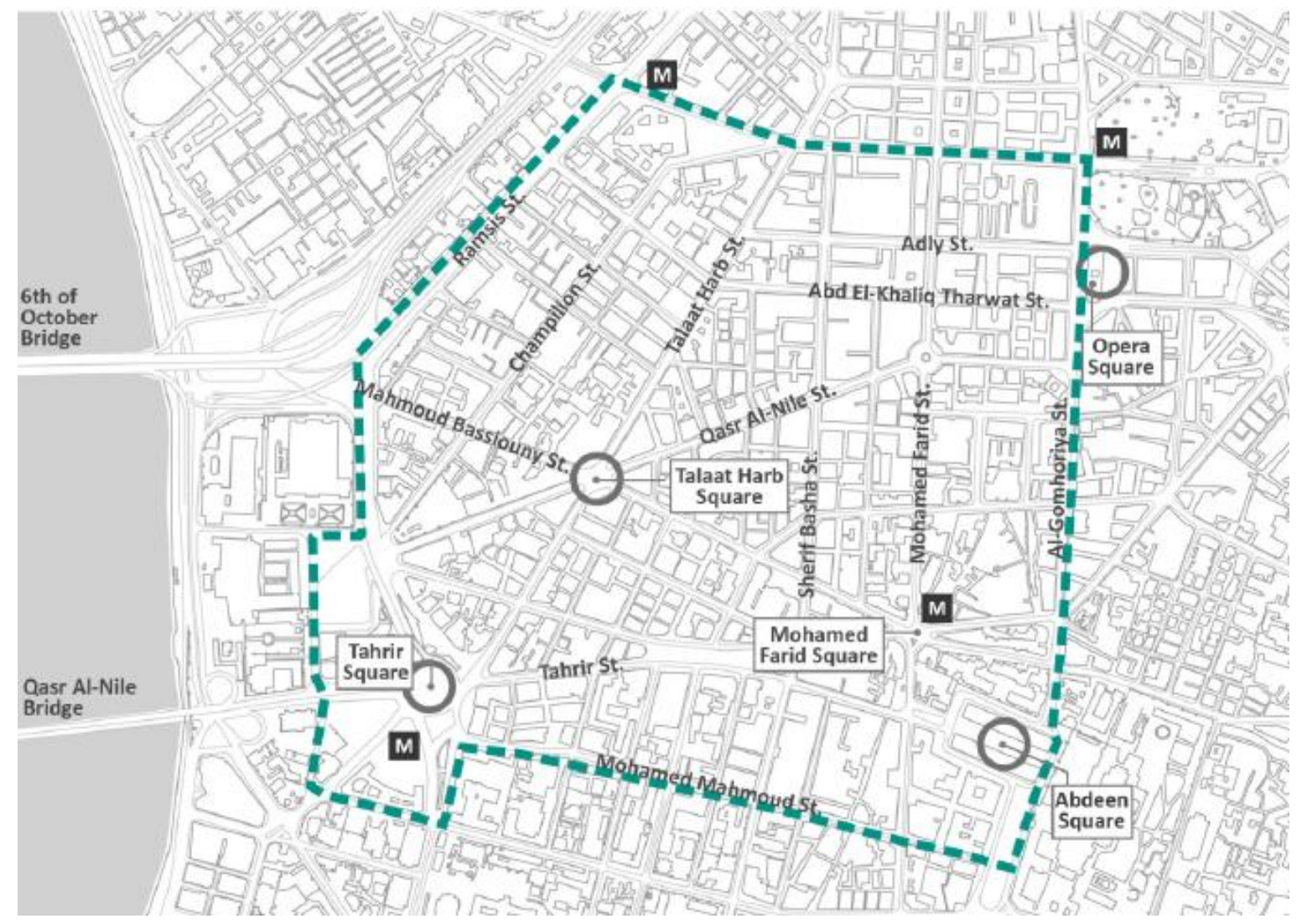

Figure 1 shows urban upgrading interventions in Downtown (Reference: Awatta,2015 )

The Governor also announced ambitious plans to transform downtown to a pedestrian-only zone, with the exception of environmentally-friendly electric buses 
that serve the area as well as rebuilding the Opera House in its original location in Opera Square [22]. Yet, these utopian plans for downtown Cairo were frozen by the unexpected revolution in 2011. The board of trustees and its fund did not rise again until 2013 under governor Galal Said, who was appointed by the temporary government after ex-President Morsi was deposed.

Later on, the board resurfaced under a different name; the Executive Committee for the Khedival Cairo Development Project. The executive committee, headed by the Governor, announced in late 2014 the undertaking of a comprehensive development project to revive Khedival Cairo. The project has two avenues of intervention; façade and public space renovation, and addressing traffic flow. The areas that went under pilot projects of renovation are; Tahrir Square, which was the first to be renovated with the façade renovation of buildings surrounding the square, which includes residential buildings, 'Umar Makram Mosque, and the Tahrir Mogamma`. The second area includes the buildings along Tal at Harb Square and Qasr al-Nil street up to Mohamed Farīd Square, in addition to a stream of increasing the capacity of streets and sidewalks along main traffic corridors, particularly Tal'at Harb and Mohamed Farīd Squares. This includes removing obstructions, such as relocating street vendors, the opening of Tahrir Garage and prohibiting parking on main traffic corridors, and upgrading sidewalks [21].

Never the less, in late 2016, a Cairo Heritage Development Committee (CHDC) was formed by a presidential decree with a mandate to examine strategies for a better future for Downtown ,drawing up a complete master plan that will balance the area's historic preservation with its economic growth potential. CHDC members include the Cairo governor, the head of the Urban Planning Organization, the head of the General Organization for Urban Harmony, the CEO of the New Administrative Capital, where many government offices currently located in Downtown buildings will be relocated, Mahmoud Abdallah, international expert in asset management, and Hisham Ezz Al-Arab, chairman of the CIB Bank and head of the Banking Association, who is responsible for financing plans. Under the development plans, the Downtown area is envisioned as a cultural and shopping hub, a tourist destination, and avenue for local people. Also some streets were pedestrianized and refurbished such as Al-Alfi and Al-Borsa as pilot projects for a future more pedestrian-friendly neighborhood center [23]. Thus based on that, the following table 1 summarizes the governorate's handful of development projects for downtown over the past fifteen years in Cairo's down town. 
Table 1: Comparing between the regeneration efforts conducted in Downtown Cairo

\begin{tabular}{|c|c|c|c|c|c|c|}
\hline & \multirow{2}{*}{$\begin{array}{c}\text { Urban heritage } \\
\text { project }\end{array}$} & \multirow[t]{2}{*}{ Year } & \multirow[t]{2}{*}{ Initiated by } & \multicolumn{2}{|l|}{$\begin{array}{l}\text { URBAN HERITAGE REGENERATION } \\
\text { STRATEGY }\end{array}$} & \\
\hline & & & & $\begin{array}{l}\text { Physical } \\
\end{array}$ & Environmental & \\
\hline \multirow{4}{*}{ 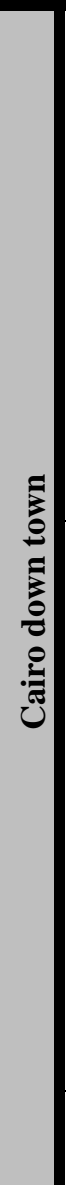 } & \multirow[b]{2}{*}{ Al-Shawarbi Street } & 1990s & $\begin{array}{c}\text { Cairo } \\
\text { Governorate }\end{array}$ & $\begin{array}{ll}- & \text { Paving roads } \\
- & \text { Installing stone benches }\end{array}$ & & \\
\hline & & $\begin{array}{c}\text { upgrad } \\
\text { ed in } \\
2016\end{array}$ & $\begin{array}{c}\text { Part of } \\
\text { Khedivian } \\
\text { Cairo } \\
\text { Rehabilitatio } \\
\text { n Project }\end{array}$ & $\begin{array}{ll}- & \text { Painting building facades } \\
- & \text { Removal of shops signage } \\
- & \text { Replacing the damaged street } \\
& \text { furniture with new marble ones } \\
- & \text { Upgrading entire street pavement } \\
& \text { with concrete and interlock tiles } \\
- & \text { Applying infrastructure works and } \\
& \text { piping } \\
-\quad & \text { Installing flower pots without } \\
\text { planting trees }\end{array}$ & & . \\
\hline & \multirow[t]{2}{*}{$\begin{array}{l}\text { Three-zone plan to } \\
\text { revitalize down town } \\
\text { (buildings } \\
\text { overlooking 6th of } \\
\text { October bridge } \\
\text { looking over Ramsis } \\
\text { street up till `Abd al- } \\
\text { Min'im Rīạd Square; } \\
\text { buildings and } \\
\text { repaving in Talat } \\
\text { Harb Square; and } \\
\text { then Qasr Al-Nile } \\
\text { street from Opera up } \\
\text { to Tahrir Squares.) }\end{array}$} & 2010 & $\begin{array}{c}\text { Cairo } \\
\text { Governorate }\end{array}$ & $\begin{array}{l}\text { Façade-repainting of several } \\
\text { buildings in Tahrir and Tal'at Ḥarb } \\
\text { Squares and Ramsis street } \\
\text { The renovation of Emad El Dine } \\
\text { street and numerous iconic } \\
\text { buildings such as the commercial } \\
\text { centers (the Stock Exchange and } \\
\text { several national banks } \\
\text { headquarters), department stores, } \\
\text { cultural centers, Radio Building, } \\
\text { Riche Café and others }\end{array}$ & & 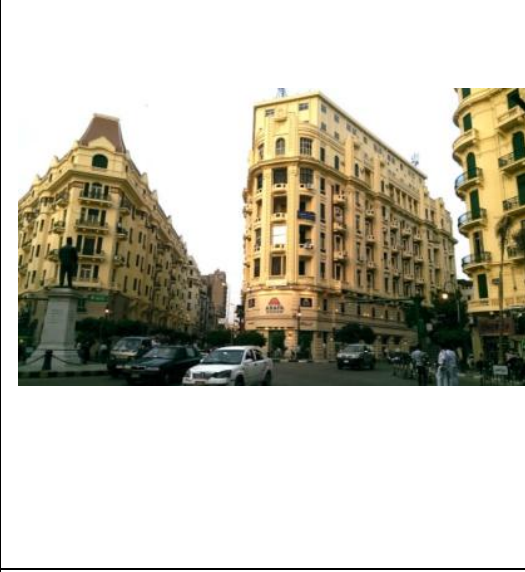 \\
\hline & & & $\begin{array}{l}\text { The } \\
\text { Executive }\end{array}$ & $\begin{array}{l}\text { Façade renovation of Tahrir square } \\
\text { and some surrounding buildings }\end{array}$ & $\begin{array}{l}\text { Adding green } \\
\text { elements to the }\end{array}$ & \\
\hline
\end{tabular}




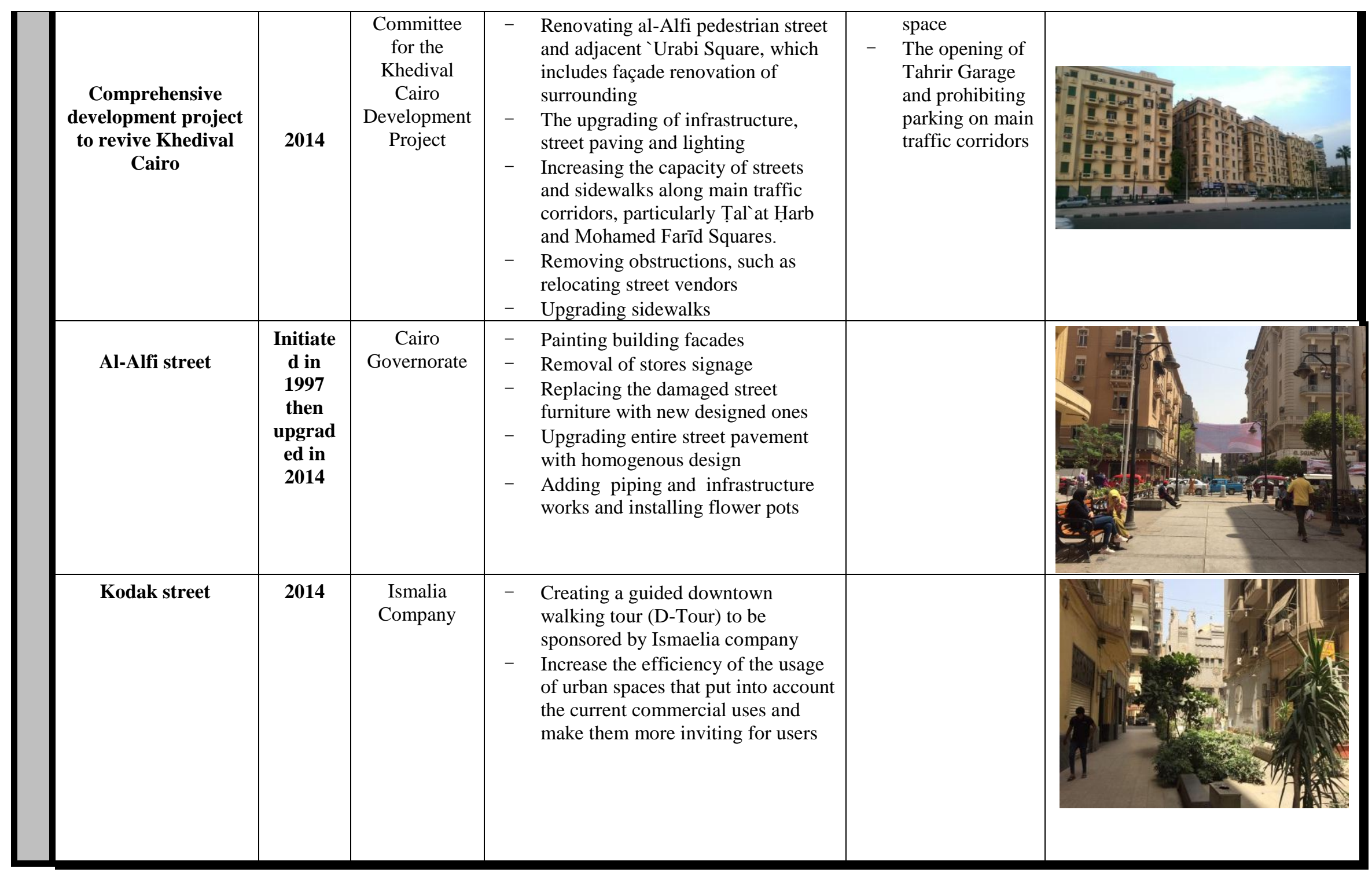


Based on the above mentioned table analyzing the efforts conducted in downtown Cairo, there are some shortcomings observed such as:

- Although they had some utopian ideas for revitalizing downtown Cairo, yet it ended up focusing on mostly the physical aspect; which is always on improving the aesthetics of downtown through façade renovation, ignoring the art of city construction and traditional planning, with some infrastructure upgrading; in the form of sidewalk repaving.

- Little to no attention is paid to land use inadequacies, or on improvement of services, strategies to utilize vacant units or rehabilitation of interior buildings.

- There is no upgrading for the socio economic aspects, within a clear vision for the overall functionality of the area, as they were conducted without the support of impact studies, and are rather isolated.

- It may be said that with rare exceptions, they have failed to develop resources linked to the developments, which are necessary to improve the local economies, providing acceptable living standards, as well as raising the cultural and societal awareness of their value, thus guaranteeing their sustainability.

- There was also no Emphasis on revitalization and preservation of old textures to recreate internal parts of city, and no criticizing for modernistic urbanization as the cars and transportation are invading the street with no plan for limiting their access, which encourages driving over walking, where walkability was not considered in the conservation plan

- Not to mention that, they did not consider the development against scattered and suburban limitless development; the plan did not address new urban theories such as new urbanism, intelligent growth, disagree with scattered development and sustainable urbanization.

- There was no coordination with market needs and views and different income classes as their main focus was on physical aspect ignoring socio economic.

- Security and safety were not fully addressed ; there are many hazards in the streets such as Motor-cycle accessibility, no continuity in the pedestrianized streets, the Marble Benches are not comfortable enough in the different seasons, with little attention given to trees and shading devices. There is also no greenbelt around streets; never the less parking problems and the accessibility to the street were not tackled professionally.

- They did not upgrade the public transportation nor use today technological new public transportation systems to encourage walking and ensure safety.

- The Hierarchy of streets, bolivars and lanes was not planned and conserved.

- The relation between interiors and exteriors was not considered as diversity in the mixed use was not comprehensively studied

\section{New urbanism Theory:}

New urbanism or traditional designing of neighboring units had been one of the newest programming approaches in urban design and suburbs of American cities which had been formed from $80-90$ decades of the $20^{\text {th }}$ century. This movement and 
new urban planning outlook is one of common attempts for solving problems of urban centers and unsustain ability of suburbs of metropolises and big cities. It aims at creating a suitable atmosphere, considering the humanistic scale that is responsible for urban transformations and the growing modern improvements demands. Therefore, changing programming point of views and urban designing towards humanistic new urbanism is necessary due to the fact that most of problems of nowadays cities because of the mechanical outlooks instead of humanistic outlook in cities.

New Urbanism movement attempts to achieve two major goals; creating a greater sense of community by accommodating more diversity of land uses and social communication in neighborhoods and by reconsidering the public realm, especially the standard streetscape and the public spaces. And to reorient the typical community toward a pedestrian- and transit-friendly environment, while also minimizing negative traffic and environmental effects. The New Urbanism is likely to play an important role in directing future development and redevelopment of metropolitan areas throughout the country [24].

Also, new urbanism provides set of principles its main points directed towards planning walkability and livable neighboring units in order to create friendly environment for pedestrians. However, it is not aiming at removing automobile, yet it attempts to create a scene of comfort and security, with satisfaction and convenience for pedestrians in spite of cars move along city, as the need for close contacts and interaction between people is generally. In the new urbanism point of view, connection of neighboring units with the surround environment is addressed and it supports urban centers and open spaces for all residents [25].

However, New Urbanism is applicable at all scales, it uses the latest construction methods, accommodate automobiles, incorporate advanced communications technologies, provide live-work dwellings, and actually match better with emerging demographic and economic trends [26]. Applications of New Urbanism's revitalization involve many conditions, including the replacement or retrofit of public housing projects, brownfield redevelopment initiatives, garden urban infill projects of all shapes and sizes, within a transit oriented development [27].

To summarize, one can say that, the 'New Urbanism' movement emerged to solve the conflict between the new developments' sprawl pattern and the need for capturing the traditional sense of community and its subsequent behaviors. The movement principles configure its conceptual understanding to much more than just an idealistic visionary one. So, its main characteristics include as following:

-Emphasizing on revitalization and preservation of old textures and cities and recreate internal parts of city.

- Criticize modernistic urbanization.

- Considering to development in available urban textures against scattered and suburban limitless development.

-Attempt to create relatively high congestion, walkable and having mixed use.

-Mix subjects such as architecture styles, intelligent growth, disagree with scattered development and sustainable urbanization. 
-Emphasis and priority on human role in urban design and planning.

-Define and use «block, street and building», «neighborhood, district and corridor», «area, metropolitan, city and town», as considerable elements of urbanization in planning design.

-Attempt to coordinate with market needs and demands and different needs and views and different income classes.

-Attempt to return to art of city construction and traditional planning while being aware of today needs of community.

-Support security, safety and health of residues.

-Having ability to localized principles of new urbanism in different communities with emphasis on available practices.

-Use today technological findings such as new public transportation systems like subway and urban style transportation systems.

-Most of uses should locate in distances suitable for walking from house to office.

-Street design should done appropriate for pedestrians (buildings adjacent to sidewalks, streets having greenbelt around them, street lots, hidden parking spaces and lots, low speeds of cars and ...).

- Hierarchy of narrow streets, bolivars and lanes.

- Diversity Mix of shops, offices, apartments and houses around design.

-Quality Architecture \& Urban Design Emphasis on beauty, aesthetic, human welfare and beautiful environment are caused to make human spirit convenient [28].

\subsection{Orenco Station as an application for new Urbanism theory :}

Orenco Station is a neighborhood of Hillsboro city, Oregon in the United States. It was built on a land formerly owned by the Oregon Nursery Company. The community was established in 1905 as a company town, within a 1200-acre $\left(4.9 \mathrm{~km}^{2}\right)$ area. The Oregon Electric Railway was established in 1908, with many original dwellings that are still standing today of the original town, such as the church, a gas station, general store. During the Great Depression, the company went out of business, the municipal corporation was dissolved with many other businesses shut down and many residents moved away in 1938, and much of the nursery land became vacant until a re-development began in 1997 [29].

Alan Ehrenhalt ${ }^{5}$, writing in the New York Times, mentioned that the planned community of Orenco Station is considered one of the most promising models of New Urbanism in the United States, and that the neighborhood has all the tools to achieve that. As it is transit oriented, social able, with high density, mixed use buildings, with many public spaces, which makes it very walkable, with awidespread network of sidewalks making the center of the town not more than 20 minutes away, as shown in figure 2 .

\footnotetext{
${ }^{5}$ Ehrenhalt is a journalist and author, he was the former executive editor and current senior editor of Governing, and he has been a contributing writer to The New York Times, The New Republic and The Wall Street Journal
} 


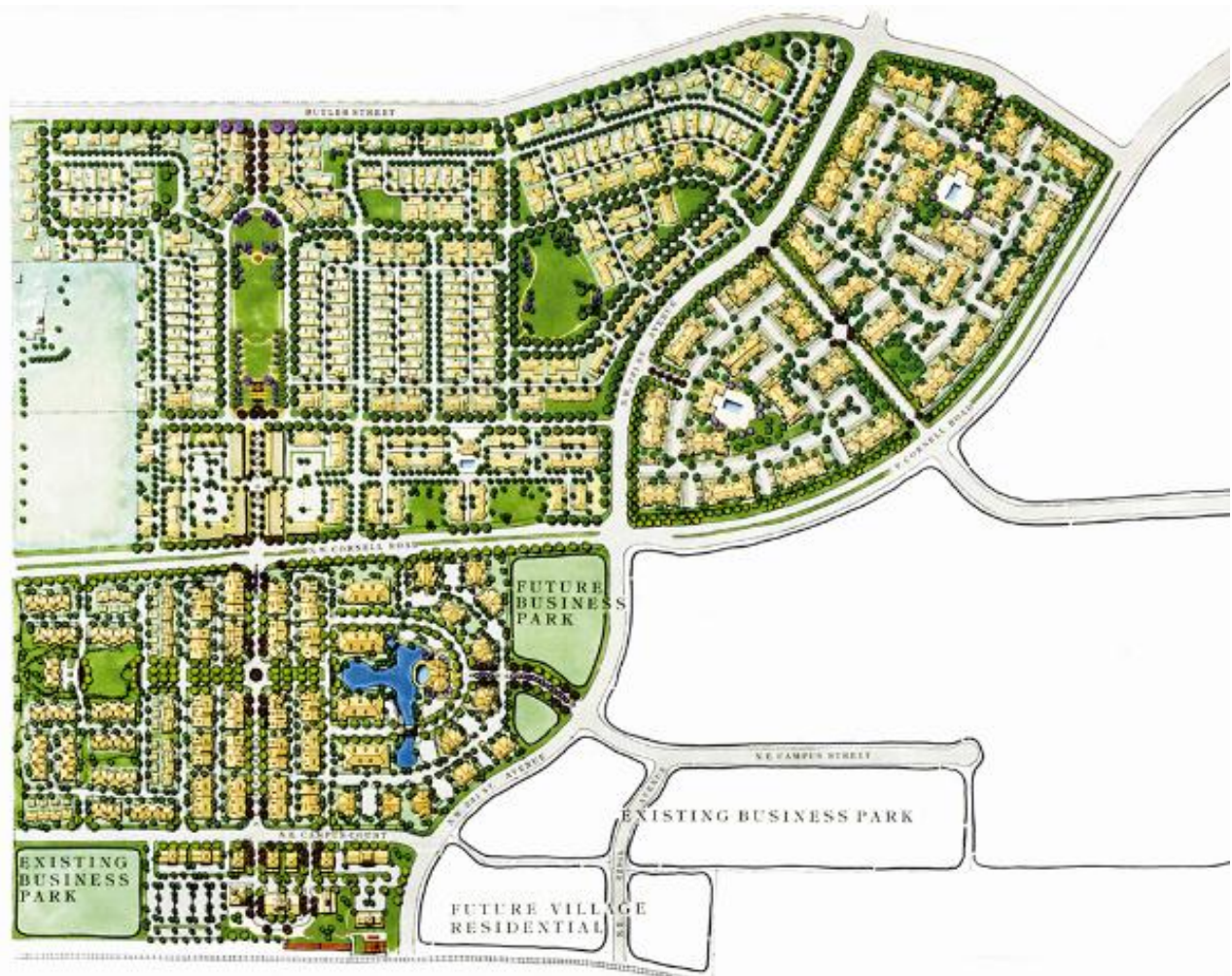

Figure 2 shows the urban planning of Orenco station with a network of sidewalks (Reference: https://newurbanisminthenews.wordpress.com/tag/orenco-station/, accessed in 2018)

\subsection{Urban intervention and regeneration:}

The site of Orenco was a green field site, between downtown Portland and downtown Hillsboro, and surrounded by thousands of high tech jobs but very little housing. After World War II, Orenco gave way across the country to the familiar pattern of postwar sprawl. The light rail line was replaced with governmentsubsidized freeways and roads. Walkable streets were replaced with spaghetti culde-sac neighborhoods and arterials, while mixed-use neighborhoods were replaced with single-use strip malls and office parks. Everything was accessible almost exclusively by car .However, after light rail funding was approved and the Town Center designation was made, the developers of Orenco Station (PacTrust and Costa Pacific Homes) created a team of architects, landscapers, engineers, and experts in homebuilding and retail, and they all worked with members of the local jurisdictions in order to plan the new Orenco Station. Nationally-known planners and community design experts were invited to a consultation sessions.

Afterwards, the team sat down with City of Hillsboro planners, and together wrote a strategy and vision for the site applying the new urbanism goals as follows:

- Emphasis on revitalization and preservation of old textures and cities and recreate internal parts of city: The historic architecture of the region was echoed but not copied, establishing an emotional connection to the region's history, climate and topography[30].Also the old suburb has been reborn, with 
the same neighborhood structure, considering to development in available urban textures against scattered and suburban limitless development, based on transitoriented and New Urbanism development in a suburban context [28].

- Criticize modernistic urbanization: In the Town Center, buildings are required to line the streets, with parking in the rear, a rule-breaking retail formula that has worked in practice surprisingly well, enhancing the multimodal transportation and create vital, attractive neighborhoods and communities.

- Emphasis and priority on human role in urban design and planning: the plan is organized around a pedestrian spine that extends north from the light rail through row homes to the Town Center, and beyond to a formal central park surrounded by a grid of walkable streets .sidewalks and pathways ensure that all residents can walk to shops in the town center. In addition to reducing the need to use cars .Also, the community offers many different features to draw the eye, including small and large parks.

- Define and use «block, street and building», «neighborhood, district and corridor», «area, metropolitan, city and town», as considerable elements of urbanization in planning design : the plan was based on skinny streets (20 foot), close street setbacks with maximum of 19 feet, with a side yard allowing high privacy windows for homes whereas the neighboring home has full use of the side yard. They also designed granny flat accessory residences, live/work homes, and garages.

- Support security, safety and health of residues : sustaining a remarkably high level of friendliness and social interaction amongst its residents. Providing Group activities in Orenco Station, to be more directed towards socializing for its own sake, that would enhance safety issues and increase surveillance.

- Having ability to localized principles of new urbanism in different communities with emphasis on available practices: engaging the residents of Orenco Station in a wider variety of social activities [30]. Representing one of the most unique urban developments in the Metropolitan area, by applying one of the central goals of New Urbanism developers, which is increasing walkability and creating physical spaces that foster new types of social interactions. [27].

- Use today technological findings such as new public transportation systems like subway and urban style transportation systems: It is transit friendly; located about a half hour west of Portland on the Westside light rail line, which makes it possible to live there without a car [29].

- Most of uses should locate in distances suitable for walking from house to office: residents will be encouraged to walk to a local store or to shops several times a week. This would increase the local pedestrian mobility, which is most likely to improve the health of Orenco residents for the long term. [30].

- Street design should be appropriate for pedestrians: Garages are located at the back of units, so that pedestrians experience a more socially inviting landscape in Orenco than is found in other neighborhoods, ensure that all 
residents can walk in sidewalks and pathways to shops in the town center safely, in addition to a numerous parks and gathering spaces. [29].

- Diversity Mix of shops, offices, apartments and houses around design: The Town Center's retail users have been carefully developed as mixed use to address the community's regular uses and needs, and include a cleaner, dentist, optician, florist, accountant, stockbroker, coffee house, wine shop, and three local restaurants, while enhancing the multi-modal transportation and create vital, attractive neighborhoods and communities all in a reasonable walking distance.

- Quality Architecture \& Urban Design Emphasis on beauty, aesthetic, human: the spatial design of the neighborhood is carefully studied offering a significantly more pleasant social atmosphere as welfare and beautiful environment are caused to make human spirit convenient [31].

However, it is worth mentioning that in 2007 a survey was conducted in Orenco station investigating the sociability compared to other neighborhoods in Portland. The survey demonstrated that it is indeed possible to achieve sustained, high levels of residential satisfaction within New Urbanism communities, as the residents of Orenco Station are engaging in a wider variety of social activities than residents in the other neighborhoods. At its early stage of the development, Orenco Station has clearly helped sustain a remarkably high level of friendliness and social interaction amongst its residents.

In total, $50 \%$ of the Orenco residents who were surveyed in 2007 reported walking to a local store or to a shop five or more times a week. Also $65 \%$ of Orenco Station residents reported that they had started using mass transit more since moving to the neighborhood. Social interactions are thriving and becoming more multi-faceted, as $40 \%$ of the residents in 2002 reported that someone in their house participated in formal or informal group activities. By 2007 this ratio had risen, so that almost $60 \%$ of respondents reported engaging in group activities. Some of the people who moved into Orenco Station did so because they wanted to live in a more sociallyinteractive community. Noting that, the development has won awards such as "Best New Burb" by Sunset magazine in 2005. Other awards include the Oregon Governor's Livability Award in 1998, the Best Master planned Community in America Award by the National Association of Home Builders in 1998, the Ahwahnee Award in 1999, and Transit Communities Livable Design Award awarded by AIA/ULI/FTA/STPP in 1999 [32].

\section{Paper Remarks :}

The Egyptian government needs to develop and form a comprehensive strategy and plan for the urban regeneration and rehabilitation projects in historic neighborhoods of the $20^{\text {th }}$ century, in order to be included in the Egyptian heritage conservation legislations and action plans, to regain back the glory of the urban heritage of the $20^{\text {th }}$ century. This would be achieved through: 
- Addressing the new urbanism theories followed in the developed countries which helped in strengthen the social environment, so consequently sustaining their urban heritage. As whenever the social bond is disappeared the area will be facing deterioration and neglect, which decreases the opportunity of proper conservation and significance of the development of our urban heritage, which would raise the awareness of the urban heritage value by engaging people again in the streets. Otherwise the local authorities will continue in their incorrect framework due to the lack of strategy and supported policies, which is also argued by Aalund (2005) [33] "any sustainable preservation of the historic city is obliged to include the social and economic aspects of development".

- provoking walkability and pedestrian friendly environment, as a comprehensive plan and approach to be included in the government plans and polices to be addressed in their regeneration projects for the entire urban area instead of working on isolated streets, which would help in engaging people again the streets and enhancing the sociability.

- Encouraging future policies which could empower the residents, private sector and NGOs to interfere through decision making and consultation.

\section{References:}

1 Birabi, A. K. (2007). international urban conservation charters:catalytic or passive tools of urban conservation practices among developing countries? . city \& time 3 (2): 4, 29-53.

2 Al-Ahram Weekly online ( 24-30 May 2001); The heart of the matter; Issue No. 535.

3 Myntti, C. ( 2003). Paris along the Nile. cairo: American University in Cairo Press.

4 Puttrowwait, E. (2014). Encouraging Bicycling as a Mean of Sustainable Urban Transportation in Cairo. Cairo: Ain Shams University.

5 Raafat,S (2003),"Cairo, the glory years", Harpocrates publishing,Alexandria

6 Macclintock, H. (2002). Planning for cycling: principles, practice and solutions for urban planners. England: CRC Press and Woodhead publishing Ltd.

7 Elsheshtawy, Y., \& ebrary, I. (2004). Planning middle eastern cities: An urban kaleidoscope in a globalizing world. New York; London: Routledge.

8 Shoup, D. (2005). The High cost of free parking. Chicago: Planner Press.

9 AlSayyad, N. (2011). Cairo: histories of a city. Cambridge, Mass: Belknap Press of Harvard University Press.

10 Eldeen, H. S. (2013). The Heart of the City from a Socio Cultural Perspective. REAL CORP 2013 Tagungsband (pp. 917-925). Rome, Italy: Manfred SCHRENK, Vasily V. POPOVICH, Peter ZEILE, Pietro ELISEI.

11 ABDEL HADI \& ElAZHARI:. Centripetal Gated Communities in Egypt; in Tolba et al. (editors) Environment, Health and Sustainable Development, Hogrefe and Huber: 2009 
12 Ayman Wanas, E. S. (2016). Social Mobility and Green Open Urban Spaces With Special Reference to Cairo. GBER Vol 10 Issue, 13-26.

13 Gharib, R. Y. (2010). Revitalising historic Cairo:examining the public policy formulation and implementation. Nottingham: University of Nottingham.

14 Raafat,S (1994) "Maadi, 1904-62; History\&Society in a Cairo suburb “,Palm Press, Cairo.

15 Abada, G. (2008). Grassroot Initiatives versus Governmental Efforts to Preserve Urban Heritage in Egypt. Cultural Heritage and Development in the Arab World (pp. 89-109). Alexandrina: Bibliotheca Alexandrina

16 Aleya Abdel-Hadi, E. E.-N. (2009). Pedestrian Street Life in Historic Cairo. International IAPS-CSBE \& HOUSING Network, (pp. 1-11). Istanbul.

17 El Kadi, G. (2005). Modern heritage in Cairo: history and current outlooks. Oxford: Blackwell Publishing.

18 GHARIB, S. (2009). Workshop "Rehabilitation of Historic Towns and Urban Sectors. Rabat,Morocco: THE NATIONAL ORGANIZATION FOR URBAN HARMONY.

19 Youssef, N. (2010). Tastamir 16 shahran girahat tagmīl li wasat al-balad. Daily Ahram. Retrieved from http://digital.ahram.org.eg/articles.aspx?Serial=101897\&eid=1768

20 Harmony, N. O. (2018, 1 24). قانون تعديلات لمناقشة مستديرة مائدة بعقد الحضاري التنسيق 144. Retrieved 10 15, 2018, from National Organization for Urban Harmony: http://urbanharmony.org/ar_news_details.asp?news_id=605

21 Awatta, H. (2015). Whose Downtown is it Anyway?The Urban Transformation of Downtown Cairo between State and Non-State Stakeholders. Cairo: The American University in Cairo.

22 Shahine, G. (2018). Saving Cairo on the Nile. Al-Ahram Weekly, 1-7.

23 S. ATTIA, Z. S. (2017). URBAN REGENERATION OF PUBLIC SPACE AL-ALFI STREET - DOWNTOWN CAIRO. the 11th International Conference on Urban Regeneration and Sustainability (Sustainable City 2016) (pp. 808-818). Cairo: WIT Press.

24 Bohl, C. (2000). New Urbanism and the City: Potential Applications and Implications for Distressed Inner-City Neighborhoods. Housing Policy Debate, Fannie Mae Foundation, Volume 11, Issue 4, 761-801

25 Hammill, Luke (2015). "The Orenco Woods saga: How the recession saved Hillsboro's planned nature park". The Oregonian.

26 Hanberg, Lou. ( 1992). Orenco Heritage Series: Book One.

27 Mehaffy, M. (2001). Orenco Station. A Journal of the Built + Natural Environments, 1-10. Retrieved from Terrain.org: https://www.terrain.org/unsprawl/10/

28 August 2012 International Journal of Applied Science and Technology199;Vol. 2 No. 7

29 JAFFE, E. (2011, OCT 10). The Limits of New Urbanism in Portland's Orenco Station. Retrieved from CITYLAB: 
https://www.citylab.com/transportation/2011/10/has-new-urbanism-failedportland/275/

30 Harvey, D., 1996. Justice, Nature, and the Geography of Difference. Cambridge: Blackwell Publishers.

31 Podobnik, B. (2011). Assessing the social and environmental achievements of New Urbanism: evidence from Portland, Oregon. Journal of Urbanism: International Research on Placemaking and Urban Sustainability, 105-126.

32 Slater, F. (1965). A History of Orenco. Retrieved from Orenco Station: http://orencostation.com/a-history-of-orenco/

33 AALUND, F. (2005). 'Islamic Cairo: Report on the ICOMOS reactive monitoring mission to World Heritage Sites.' Paris. 